American University Washington College of Law

Digital Commons @ American University Washington College of

Law

Articles in Law Reviews \& Other Academic Journals

Scholarship \& Research

2013

Economics and Politics: Perspectives on the Goals and Future of Antitrust

Jonathan Baker

Follow this and additional works at: https://digitalcommons.wcl.american.edu/facsch_lawrev

Part of the Antitrust and Trade Regulation Commons, and the Law and Economics Commons 


\title{
ECONOMICS AND POLITICS: PERSPECTIVES ON THE GOALS AND FUTURE OF ANTITRUST
}

\begin{abstract}
Jonathan B. Baker*
This Article examines the roles of economics and politics in U.S. antitrust from several perspectives. It explains why the modern debate over the economic welfare standard that enforcers and courts should pursue is unsatisfying. It connects economics with politics by describing antitrust's economic goals as the product of a mid-twentieth century political understanding about the nature of economic regulation that continues to be accepted. To protect that understanding, it explains, antitrust rules should now be implemented using a qualified consumer welfare standard. It identifies contemporary political tensions that threaten to create regulatory gridlock or even to undermine that political understanding and uses that framework to sketch several possible futures for competition policy. Notwithstanding these political tensions, the Article concludes, economics plays an indispensable role in shaping and applying modern antitrust.
\end{abstract}

\section{TABLE OF CONTENTS}

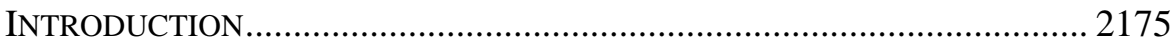

I. THE UnSATISFYING WELFARE STANDARD DEBATE........................... 2176

II. ANTITRUSt Through the LENS OF A PoliticAl BARgAin ............. 2180

III. THE END OF DEREGULATION ....................................................... 2186

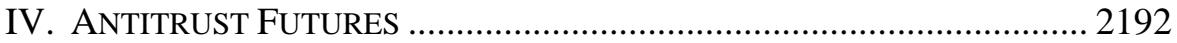

V. ECONOMICS AND POLITICS IN ANTITRUST: A CONCLUDING

COMMENT 2195

\section{INTRODUCTION}

Any modern antitrust practitioner would recognize the central role of economics in competition policy and case evaluation. Yet any student of antitrust history would see politics too_-for example, the 1912 election

* Professor of Law, American University Washington College of Law. The author is indebted to Justin Desautels-Stein, Andy Gavil, Lewis Grossman, Scott Hemphill, M.J. Moltenbrey, Fernanda Nicola, Oke Odudu, Barak Orbach, Steve Salop, and Spencer Waller. 
year debates that led to the enactment of the Clayton and FTC Acts, ${ }^{1}$ the congressional actions that prevented President Reagan's Justice Department from arguing for the repeal of the per se rule against resale price maintenance, ${ }^{2}$ and presidential candidate George W. Bush's skeptical comments about the Clinton Administration's proposed remedy in its monopolization case against Microsoft. ${ }^{3}$

This Article looks at the roles of economics and politics in U.S. antitrust from several perspectives. The first section evaluates the modern debate over the economic welfare standard that enforcers and courts should pursue. The second section connects economics and politics by describing antitrust's economic goals as the product of a mid-twentieth century political understanding about the nature of economic regulation that has continued in force to this day. To protect that understanding, antitrust rules should now be implemented using a qualified consumer welfare standard. The third section identifies contemporary political tensions that threaten to create regulatory gridlock, or even to undermine the political understanding. The fourth section uses this framework to sketch several possible futures for competition policy. The Article concludes with a comment on the indispensable role of economics in shaping and applying modern antitrust.

\section{The UnSATiSfying Welfare StANDARD DeBATE}

I have always found the debate over antitrust's goals unsatisfying. The debate first took its modern form three decades ago as a dispute between Chicagoan Robert Bork and critic Robert Lande over antitrust's origins. At that time, the argument over economic goals was a proxy battle over whether antitrust should be reformed along Chicago school lines. ${ }^{4}$ Chicagoan Robert Bork read the legislative history to defend an aggregate surplus goal, while critic Robert Lande read it to defend a consumer surplus goal. ${ }^{5}$

1. See generally Jonathan B. Baker, Competition Policy As a Political Bargain, 73 ANTITRUST L.J. 483, 497-99 (2006); Marc Winerman, The Origins of the FTC: Concentration, Cooperation, Control and Competition, 71 ANTITRUST L.J. 1 (2003).

2. See Baker, supra note 1, at 509 n.96.

3. Mike Allen, Bush Hints He Would Not Have Prosecuted Microsoft, WAsH. Post (Feb. 28. 2000, 12:00 PM), http://www.washingtonpost.com/wp-srv/pmextra/feb00/28/ A43853-2000Feb28.html.

4. Compare Robert H. Bork, The Antitrust Paradox 56-66 (1978), with Robert H. Lande, Chicago's False Foundation: Wealth Transfers (Not Just Efficiency) Should Guide Antitrust, 58 ANTITRUST L.J. 631 (1989), and Robert H. Lande, Wealth Transfers as the Original and Primary Concern of Antitrust: The Efficiency Interpretation Challenged, 34 HASTINGS L.J. 65 (1982). Other prominent commentators writing around the same time defended noneconomic goals. See, e.g., Robert Pitofsky, The Political Content of Antitrust, 127 U. PA. L. REV. 1051 (1979).

5. The consumer surplus in a market equals the aggregate benefits (willingness to pay) that the buyers collectively receive, less the expenditures those buyers make. The aggregate surplus equals the consumer benefits that buyers collectively receive less the variable costs 
As an argument over antitrust's origins, the debate foundered in part on the anachronism of interpreting the early understanding of the Sherman Act in terms of modern economic perspectives. The best interpretation of the understanding of antitrust's original generation is neither Judge Bork's nor Professor Lande's. Rather, the Sherman Act was understood then as protecting natural rights to economic liberty, security of property, and the process of free and competitive exchange from artificial interference by private actors, much as the same generation saw the Constitution's due process clause as protecting these rights from governmental interference. ${ }^{6}$ Moreover, the dispute over antitrust's origins is largely irrelevant to the goals of modern antitrust because the contemporary Supreme Court has accepted the Sherman Act's "dynamic potential."7

Nor does it help clarify the dispute over goals to talk about them in economic terms. The main difficulty is the absence of a clear way to use the economists' Pareto efficiency standard when aggregating consumption bundles across individuals, ${ }^{8}$ or when analyzing the welfare consequences of business conduct in the partial equilibrium context in which antitrust cases

of production expended by all the good's sellers. Aggregate surplus equals the sum of consumer surplus and producer surplus. The producer surplus equals the contribution to profit that sellers collectively receive from the market or, equivalently, the total payments sellers receive from buyers less the total variable costs of production. ANDREU MAS-COLELL, Michael D. Whinston \& Jerry R. Green, Microeconomic Theory 332-33 (1995).

6. See generally James May, Antitrust in the Formative Era: Political and Economic Theory in Constitutional and Antitrust Analysis, 1880-1918, 50 Оніо ST. L.J. 257 (1989); cf. Alan J. Meese, Standard Oil as Lochner's Trojan Horse, 85 S. CAL. L. Rev. 783 (2012) (describing the 1911 Standard Oil antitrust decision as an application of Lochner to antitrust). Viewed from this perspective, antitrust was originally understood as simultaneously promoting outcomes seen today as potentially in conflict, including individual business opportunity, economic efficiency, national prosperity, justice, social harmony, and personal freedom.

7. Bus. Elecs. Corp. v. Sharp Elecs. Corp., 485 U.S. 717, 732 (1988) ("The Sherman Act adopted the term 'restraint of trade' along with its dynamic potential. It invokes the common law itself, and not merely the static content that the common law had assigned to the term in 1890.”); accord Leegin Creative Leather Prods., Inc. v. PSKS, Inc., 551 U.S. 877, 888 (2007).

8. "The concept of Pareto optimality [or Pareto efficiency] offers a minimal and largely uncontroversial test that any social optimal economic outcome should pass. An economic outcome is said to be Pareto optimal if it is impossible to make some individuals better off without making some other individuals worse off. This concept is a formalization of the idea that there is no waste in society, and it conveniently separates the issue of economic efficiency from more controversial (and political) questions regarding the ideal distribution of well-being across individuals.” MAS-COLELL, supra note 5, at 307-08. But see Amartya Sen, The Impossibilty of a Paretian Liberal, 78 J. POL. ECON. 152 (1970) (demonsrating potential incompatibility between achieving Pareto efficiency and protecting individual rights). The consumer surplus and aggregate surplus criteria commonly employed in economic discussions of antitrust goals aggregate across individuals. Hence, it is not possible to tell whether an improvement in either surplus measure reflects a Pareto efficiency improvement without knowing whether those who gain compensate those who lose. 
are evaluated. ${ }^{9}$ When framed in economic language, the argument over antitrust's overarching goal is often described by commentators as a choice between a consumer surplus and an aggregate surplus standard. ${ }^{10}$ Economic thinking does not provide a clear answer, only pros and cons. The consumer surplus approach has the advantage of looking solely to consumers, the actors who are the sole concern of the Pareto criterion. The aggregate surplus approach has the advantage of also accounting for production efficiencies that would often ultimately accrue to other consumers in other markets, but it could justify conduct that makes most or all of the consumers of the product in question worse off. ${ }^{11}$ Courts and enforcers are generally wary of tolerating conduct that harms (or is likely to harm) a class of consumers, so in practice they tend to act consistently with the consumer surplus standard. ${ }^{12}$

Moreover, it can be difficult to apply an economic welfare standardwhether consumer surplus or aggregate surplus-when accounting for enforcement institutions, for four reasons. First, those institutions impose transaction costs and can make mistakes. ${ }^{13}$ Second, courts and enforcers

9. A "partial equilibrium" is the outcome that arises in a single market, without reference to the production and consumption of any other goods in the economy. Consumer surplus and aggregate surplus are defined for a single market in partial equilibrium. Problems associated with a partial equilibrium analysis may include accounting for "second best" issues that arise when other markets are not competitive, and accounting for income effects. In applying either surplus standard, it may also be difficult to discount future effects appropriately if harms or efficiencies are delayed or to account for the effects of antitrust policy on innovation and investment. See generally Barak Y. Orbach, The Antitrust Consumer Welfare Paradox, 7 J. COMPETITION L. \& ECON. 133 (2010) (distinguishing between the surplus analysis commonly used to evaluate antitrust issues and welfare analysis in economic theory); Oliver E. Williamson, Economies As an Antitrust Defense: The Welfare Tradeoffs, 58 AM. ECON. REv. 18 (1968) (framing the welfare standard issue in economic terms).

10. Practices that maximize aggregate surplus do not necessarily maximize consumer surplus, and vice versa. See Baker, supra note 1, at 516-18; Steven C. Salop, Question: What is the Real and Proper Antitrust Welfare Standard? Answer: The True Consumer Welfare Standard, 22 Loy. Consumer L. REV. 336 (2009). But cf. Terry Calvani, Rectangles \& Triangles: A Response to Mr. Lande, 58 AnTITRUST L.J. 657 (1989) (conduct with collusive anticompetitive effects often harms competition under either measure).

11. A robust tax and transfer system could prevent consumer losses. See LouIs KaPLOW \& Steven Shavell, Fairness And Efficiency 29-38 (2002). But with respect to the consumer harm from antitrust violations, that is more a theoretical possibility than a practical corrective. See Salop, supra note 10, at 350-51.

12. Salop, supra note 10, at 339; Herbert J. Hovenkamp, Implementing Antitrust's Welfare Goals 7 (Univ. Iowa Legal Studies Research, Paper No. 12-39, 2013), available at http://ssrn.com/abstract=2154499; see John E. Lopatka \& William H. Page, 'Obvious' Consumer Harm in Antitrust Policy: The Chicago School, the Post-Chicago School and the Courts, in Post-Chicago Developments in Antitrust Analysis 129 (Antonio Cucinotta, Roberto Pardolesi \& Roger Van den Bergh eds., 2002).

13. The Harvard school's focus on the administrability of antitrust rules treats transaction costs as a first-order problem. See generally William E. Kovacic, The Intellectual DNA of Modern U.S. Competition Law for Dominant Firm Conduct: The Chicago/Harvard 
may be at an information disadvantage relative to firms. Under such circumstances, the best way for antitrust institutions to pursue either welfare goal may be to do so indirectly. In some settings, for example, a commitment to a consumer welfare approach will maximize aggregate welfare. ${ }^{14}$ Third, if legal rules are designed to pursue a particular goal, their design must account for error costs, understood broadly to include deterrence. ${ }^{15}$ But the error costs of any particular substantive antitrust rule depend on other rules of antitrust law and beyond, such as procedural rules governing litigation, rules about remedy determination, the scope of intellectual property rights, and whether state unfair competition laws cover the same conduct. ${ }^{16}$ Fourth, it can be particularly challenging to evaluate the welfare consequences of practices that benefit consumers in the short run but may harm them in the long run, as with predatory pricing. With these four complications added to the initial difficulty of choosing between consumer surplus and total welfare, it is hard to be confident that any particular legal rule will minimize error costs for any of the issues antitrust commentators argue about, like bundled discounts or the unilateral competitive effects of mergers, even with the best of intentions. ${ }^{17}$

Double Helix, 2007 Colum. Bus. L. REv. 1 (2007). The problem of evaluating efficiency claims in merger analysis provides an example. Judge Posner has described doing so as "a matter of speculation flavored by hope.” RICHARD A POSNER, ANTITRUST LAW 133 (2d ed. 2001). Antitrust enforcement has not accepted Posner's view, for example, see U.S. DEP'T of Justice \& Fed. Trade Comm’n, Horizontal Merger Guidelines § 10 (2010) [hereinafter HORIzONTAL MERgER Guidelines], available at http://www.justice.gov/ atr/public/guidelines/hmg-2010.pdf, but if Posner is correct, courts are less likely to make mistakes when applying a consumer welfare standard than an aggregate surplus standard, as the consumer surplus criterion avoids the need to analyze fixed cost savings.

14. See David Besanko \& Daniel F. Spulber, Contested Mergers and Antitrust Policy, 9 J.L. ECON. \& ORG. 1 (1993); Joseph Farrell, Negotiation and Merger Remedies: Some Problems, in MERger Remedies in AMERICAN AND EuROPEAN COMPETITION LAW 95-105 (Francois Leveque \& Howard Shelanski eds., 2003); Damien J. Neven \& Lars-Hendrik Roller, Consumer Surplus vs. Welfare Standard in a Political Economy Model of Merger Control, 23 INT'L J. INDUS. ORG. 829 (2005); Sven-Olof Fridolfsson, A Consumer Surplus Defense in Merger Control (IFN, Working Paper No. 686, 2007).

15. Error costs are the costs of false positives and false negatives, not just in the individual matters under review but also in potentially chilling procompetitive conduct or failing to deter anticompetitive conduct in the future, in the same or other markets. False positives and false negatives may not neatly map to overdeterrence and underdeterrence, respectively, because the deterrence consequences of legal errors depend in part on the way the errors affect the marginal costs and benefits to firms of taking precautions to avoid violations. See generally Warren F. Schwartz, Legal Error, in ENCYCLOPEDIA OF LAW AND ECONOMICs 1029-40 (Boudewijn Bouchaert \& Gerrit De Geest eds., 2000).

16. See generally Louis Kaplow, Burden of Proof, 121 YALE L.J. 738 (2012); Abraham L. Wickelgren, Determining the Optimal Antitrust Standard: How To Think About Per Se Versus Rule of Reason, 85 S. CAL. L. REV. (POSTSCRIPT) 52, 54 (2012), http://weblaw. usc.edu/why/students/orgs/lawreview/documents/85SCalLRevPS_85Wickelgren.pdf.

17. See Hovenkamp, supra note 12, at 11 (describing the difficulties with evaluating the welfare consequences of tying and resale price maintenance); Jonathan B. Baker, Exclusion As a Core Competition Concern, 78 ANTITRUST L.J. 527 (2013) (discussing alternative views 
For these reasons, it is no surprise that after decades of doctrinal elaboration under an economic approach, the antitrust community has not reached a durable consensus over the economic goal that antitrust enforcement should pursue. Indeed, it is unlikely that the community will ever identify a precise objective function that the antitrust laws should or do maximize, or that any approach to defining antitrust's goals can supply the precision, clarity, and certainty that the open-ended Sherman Act does not provide. ${ }^{18}$ Judges are not asked to specify or apply legal rules in order to advance a unitary goal in other legal fields. Unless antitrust is special, the antitrust community's pursuit of a unitary goal is asking too much.

This Article is not suggesting that economic analysis should take a back seat to noneconomic concerns. In fact, the next section explains why antitrust in the modern era has always had a generalized economic goal, even during the Warren Court era when social and political concerns counted for more than they do now. It is also not suggesting that antitrust enforcers and courts should decide cases arbitrarily. The next section will also explain why the antitrust rules today should be implemented through a qualified consumer welfare standard. The point here is narrow: we should not talk about the antitrust field as though we just have to settle one pesky detail-whether to select aggregate surplus or consumer surplus as the appropriate goal-in order to reach the end of antitrust history.

\section{Antitrust Through the Lens of A POLITICAL BARGAin}

Our conversation about the goals of antitrust is unusual when compared with the way legal scholars talk about other fields. My sense, which I will sketch but not defend in detail, is that two sweeping intellectual projects animate much of contemporary legal scholarship, ${ }^{19}$ rooted in different conceptions of the public good. ${ }^{20}$ When antitrust discourse is located

over the application of error cost analysis to the evaluation of rules governing exclusionary conduct); cf. Memorandum from Jonathan B. Baker \& M. Howard Morse, Final Report of Economic Evidence Task Force to Officers and Council (Aug. 1, 2006), available at http://www.abanet.org/antitrust/at-reports/01-c-ii.pdf (describing the difficulties facing generalist judges in evaluating economic evidence).

18. The Sherman Act describes prohibited conduct in extremely general terms. Sherman Act section 1 forbids agreements "in restraint of trade" and Sherman Act section 2 forbids conduct that "monopolize[s]" or "attempt[s] to monopolize.” 15 U.S.C. §§ 1-2 (2006).

19. I emphasize these two projects because they are important to legal scholarship and provide helpful context for thinking about antitrust, but I do not contend that they encompass every important academic school of thought. Indeed, surveys of modern U.S. jurisprudence commonly identify multiple schools. See, e.g., THE CANON OF AMERICAN LEGAL THOUght 7 (David Kennedy \& William W. Fisher III eds., 2006) (identifying eight schools: Legal Realism, Legal Process, Law and Economics, Law and Society, Critical Legal Studies, Modern Liberalism, Feminist Legal Thought, and Critical Race Theory).

20. In some deep sense, both projects seek to ensure that the law and the market fulfill their common promise of harnessing private incentives to advance the public good. But they differ in focus: the first emphasizes the contribution of political and economic rights to that 
within this framework, the idea that antitrust must be about maximizing either consumer surplus or aggregate surplus seems even less appealing. ${ }^{21}$

In broad strokes, the first project is concerned with encouraging democratic participation and seeking social justice. ${ }^{22}$ This project celebrates, for example, the expansion of the franchise, the inclusion of minority groups into mainstream life, the assurance of economic security for the less fortunate, and the recognition and protection of civil rights. ${ }^{23}$ The second project is concerned with creating social wealth, improving living standards, capturing efficiencies and fostering economic growth. This project predated the law and economics movement, but that scholarly approach has made the second project more important in legal academia. ${ }^{24}$

good, while the second emphasizes the contribution of economic efficiency and economic growth.

21. Cf. Neil Duxbury, Patterns of American Jurisprudence 363 (1995) ("While Chicago may have dominated the struggle for the soul of antitrust, it is a struggle which seems destined to continue.”).

22. E.g., Bruce A. Ackerman, Social Justice in the Liberal State (1980); John Hart Ely, Democracy and Distrust (1980); see also Michael J. Gerhardt \& ThOMAS D. Rowe, Jr., Constitutional Theory: Arguments and Perspectives 195 (1993) (describing liberalism, in its various forms, as the dominant perspective in constitutional theory for much of the second half of the twentieth century).

23. This is mainly a progressive project, see LAURA Kalman, THE STRANGE CAREER of LEGAL LIBERALISM (1996), though it has a conservative variant that contests which rights are primary and emphasizes securing economic rights to property and freedom of contract. E.g., Richard A. EPSTEIN, Simple Rules FOR A COMPlex World (1995); $c f$. Justin DesautelsStein, The Market As a Legal Concept, 60 Buff. L. Rev. 387 (2012) (distinguishing the classical/neoliberal view of the market and state, which emphasizes the role of background law in creating markets, from modern liberalism, which also charges the state with using law to address market failures, and critiquing both). I think of Critical Legal Studies as a variant that emphasizes the malleability of the law and argues that as a result, legal rules tend to serve the powerful. If so, progressive legal victories are reversible, so constant political mobilization by the less powerful is needed to protect and extend any gains they make. This voice has rarely been heard in modern antitrust scholarship. But cf. Richard Brunell, Appropriability in Antitrust: How Much Is Enough?, 9 ANTITRUST L.J. 1 (2001) (arguing that the indeterminacy of appropriability arguments in antitrust limits the usefulness of economics as a guide for antitrust policy); Duncan Kennedy, Law-and-Economics from the Perspective of Critical Legal Studies, in 2 The New Palgrave Dictionary of ECONOMics AND THE LAW 465 (1998) (highlighting distributional implications of mainstream law and economics thought generally); Justin Desautels-Stein, Liberal Legalism and the Two State Action Doctrines, 6 N.Y.U. J.L. \& LIBERTY (forthcoming 2013) (on file with author) (arguing that the antitrust state action doctrine and the constitutional state action doctrine share a liberal conception of the role of law in governing markets).

24. See, e.g., Richard A. Posner, Economic Analysis of LAW (7th ed. 2007); $c f$. William E. Nelson, Horwitz and the Direction of Legal Thought, in 2 TrANSFORMATIONS IN American Legal History 500, 501 (Daniel W. Hamilton \& Alfred L. Brophy eds., 2010) ("Law and economics scholars claim the ability in a wide range of fields to bring about ... Pareto improvements in doctrine, and it is not surprising that they are rapidly colonizing those fields.”). 
Before the 1980s, antitrust might have appeared to bridge both projects. During antitrust's structural era, 25 courts and commentators talked about themes that sound like democratic participation, such as ensuring all producers a fair opportunity to compete, preventing the exploitation of consumers and farmers, and limiting the political power of large firms. ${ }^{26}$ But antitrust discourse then was also concerned with allowing firms to obtain production efficiencies and promoting economic growth. ${ }^{27}$

Antitrust's Chicago school revolution discarded talk of social and political goals and reframed antitrust to focus solely on economic concerns. But that observation does not mean that antitrust was part of both projects during the structural era and only part of the economic growth project since that time. Rather, the social and political concerns that formed part of the antitrust conversation during the earlier period were instrumental, not essential. Since the New Deal, as I will explain, antitrust has always been about the second project: about capturing economic efficiencies by adopting competition policy in preference to either less regulatory or more regulatory approaches that were also live options in the early twentieth century political debate about dealing with large firms.

The argument for this claim is in previous work in which I interpret competition policy, broadly defined, as a political choice made at the end of the New Deal for dealing with the growth of large firms in an industrial economy. ${ }^{28}$ That choice resolved a central political concern of U.S. politics during the late nineteenth century and the first few decades of the twentieth

25. I demarcate three major eras of antitrust interpretation: classical (1890 to the 1940s), structural (1940s through the 1970s), and Chicago school (since the late 1970s). Jonathan B. Baker, A Preface to Post-Chicago Antitrust, in Post-ChiCAgo Developments In ANTITRUST ANALYSIS, supra note 12, at 60-67.

26. See, e.g., BoRK, supra note 4, at 54-56 (1978) (criticizing political concerns recognized by the then-current case law); William H. Page, The Ideological Origins and Evolution of U.S. Antitrust Law, in 1 Issues in COMPETITION LAW AND POLICY 1, 7-10 (Wayne Dale Collins et. al. eds., 2008) (describing populist concerns characterizing antitrust from the New Deal through the Warren Court); Pitofsky, supra note 4, at 1052-60 (favoring some commonly cited social and political goals while opposing others). When Justice Thurgood Marshall described the antitrust laws as "the Magna Carta of free enterprise" and "as important to the preservation of economic freedom . . . as the Bill of Rights is to the protection of our fundamental personal freedoms," he no doubt had in mind these types of concerns. United States v. Topco Assocs., Inc., 405 U.S. 596, 610 (1972); see also N. Pac. Ry. Co. v. United States, 356 U.S. 1, 4 (1958) (“charter of economic liberty”); United States v. Socony-Vacuum Oil Co., 310 U.S. 150, 221 (1940) (“charter of freedom”); Appalachian Coals, Inc. v. United States, 288 U.S. 344, 359 (1933) (same).

27. Carl Kaysen \& Donald F. Turner, Antitrust Policy: An ECONOMiC And Legal ANALYSIS 13-14 (1959) ("To sum up, efficiency and progressiveness [productivity growth and innovation] are the most important economic results whose achievement can be substantially influenced by antitrust policy.”).

28. See generally Baker, supra note 1; Jonathan B. Baker, Preserving a Political Bargain: The Political Economy of the Non-interventionist Challenge to Monopolization Enforcement, 76 ANTITRUST L.J. 605 (2010). 
century. The U.S. political system could have adopted a more interventionist regulatory approach involving industrial policy and direct regulation. Although many sectors of the economy, including communications, energy, financial services, and transportation were heavily regulated - often with prices set by regulators - in most of the economy, firms were generally allowed to compete. The United States could have also adopted a less interventionist self-regulatory or laissez-faire approach, relying on private enterprise to organize production and trade with little or no supervision to ensure that firms competed. These were both seriously debated alternatives with decades of strong political backing. ${ }^{29}$ Instead, the United States adopted competition policy as the primary approach to economic regulation, in order to reach a generalized economic goal of obtaining and sharing the efficiency benefits of competition. I call that informal understanding a "political bargain."30 This understanding accounts for the depoliticization of antitrust since the 1940s, thus providing an answer to the question historian Richard Hofstadter asked in 1964: "What Ever Happened to the Antitrust Movement?"31 In addition, this framework highlights the important role of antitrust institutions in implementing an economic regulatory policy framed around competition, though other institutions, including sector regulators, also play a role.

The political bargain adopted competition policy in preference to regulation or laissez-faire, but it did not freeze antitrust rules. When the bargain was reached, the main theme of antitrust was to ensure close scrutiny of large firms in concentrated markets. The major changes in antitrust dating around 1980, associated with the rise of the Chicago school, reformed the bargain in order to increase the efficiency benefits of competition, primarily by removing impediments to achieving production efficiencies.

On this account, antitrust policy since the New Deal has always had an economic goal. The social and political concerns that antitrust discarded when the rules were reformed had been instrumental: useful touchstones for ensuring political support, but not essential to antitrust. Since the midtwentieth century, antitrust has fundamentally been about capturing economic efficiencies by adopting a policy that favors competition over either less regulatory or more regulatory approaches, but antitrust policy

29. Baker, supra note 1, at 497-503; see Winerman, supra note 1, at 15-43 (describing positions held by Roosevelt, Taft, Brandeis, and Wilson in the debate leading to the enactment of the FTC and Clayton Acts).

30. The political economy argument offered to support this perspective interprets political outcomes in terms of interest group competition but does not assume that a welfareenhancing policy such as this one is the inevitable product of Coasian bargaining among conflicting interest groups or the product of evolutionary selection. Baker, supra note 1, at 485-93. The welfare-enhancing policy instead arises as an equilibrium made feasible by the repeated noncooperative political interaction of two interest group coalitions. Id. at 524-30.

31. Richard Hofstadter, What Happened to the Antitrust Movement?, in THE PARANOID STYle In AMERICAN POLITICS, AND OTHER ESSAYs 188 (1965). 
does not bend every aspect toward economic efficiency because it must protect its political support. ${ }^{32}$

In this story, the political bargain constrains the antitrust rules as a whole, but it does not constrain the rules individually. ${ }^{33}$ The institutions that foster and protect competition will preserve their political support so long as enough of the benefits go to the two diffuse interest groups that reached the informal understanding: consumers, farmers, and small business on the one hand, and large firms on the other. The bargain will persist so long as neither group thinks it can do better by giving up on it and mobilizing politically to seek a different policy. The resulting bounds have left a great deal of room within which the courts can maneuver, particularly in specifying the details of antitrust doctrine.

From this perspective, antitrust rules capture efficiencies, but their distributional consequences are important because competition policy needs to maintain political support. The rule changes prompted by Chicago school arguments likely increased aggregate welfare by addressing a concern that the earlier rules were chilling production efficiencies. But the Chicago-oriented rule modifications likely also tended to redistribute surplus from consumers to large firms by increasing the risk that firms will exercise market power.

To see this distributional point, compare the structural era antitrust rules, established from the 1940s to the mid-1970s, with the more recent approach. Before Broadcast Music, Inc. v. Columbia Broadcasting Systems, Inc. ${ }^{34}$ the per se rule against horizontal restraints was not limited to naked restraints. Before Matsushita Electric Industrial Co. v. Zenith Radio Corp, ${ }^{35}$ it was easier to survive summary judgment when inferring an agreement from circumstantial evidence. During antitrust's structural era, horizontal mergers were strongly presumed to harm competition. ${ }^{36}$ Before Continental T.V., Inc. v. GTE Sylvania Inc., ${ }^{37}$ some non-price vertical restraints were illegal per se, and before Leegin Creative Leather Products, Inc. v. PSKS, Inc., ${ }^{38}$ resale price maintenance was often illegal per se. ${ }^{39}$

32. This frame offers a way to discuss the role of politics in shaping antitrust that is rooted in the interest group competition approach of positive political theory and recognizes the centrality of economics to antitrust analysis.

33. Individual case outcomes may depend on a mix of substantive and procedural rules. Cf. Stephen Calkins, Summary Judgment, Motions To Dismiss, and Other Examples of Equilibrating Tendencies in the Antitrust System, 74 GEO. LJ. 1065 (1986) (showing how the antitrust treble damages remedy has shaped substantive and procedural antitrust law across doctrinal categories).

34. 441 U.S. 1 (1979).

35. 475 U.S. 574 (1986).

36. See, e.g., United States v. Von’s Grocery Co., 384 U.S. 270 (1966).

37. 433 U.S. 36 (1977).

38. 551 U.S. 877 (2007)

39. Between the 1950s and mid-1970s, however, Congress gave states the authority to permit resale price maintenance agreements in certain industries, and during the 1980s the 
The United States v. Aluminum Company of America ${ }^{40}$ court found monopolization from conduct unlikely to be considered sufficient today: a dominant firm's expansion of capacity in advance of demand. ${ }^{41}$ Predatory pricing was accepted as a possible anticompetitive strategy during the structural era, and rivals were viewed as appropriate parties to vindicate antitrust principles as private attorneys general, but these views are more controversial today. ${ }^{42}$

The old rules each likely deterred more anticompetitive conduct than the corresponding modern rules do now. But in general, the rules were modified for a good reason: they chilled cost reductions and other efficiency-enhancing conduct. ${ }^{43}$ The rule modifications addressed that problem by reducing the risk of false convictions. In accomplishing that end, they systematically accepted a greater risk of false acquittals. As a result, the risk that firms would exercise market power has likely increased. ${ }^{44}$ Continued rule modifications in the same vein, toward the noninterventionist side of competition policy disputes, would also increase the risk that exploited consumers would give up on the political bargain by

Supreme Court narrowed the application of the per se rule by elevating standards of proof. See Andrew I. Gavil, William E. Kovacic \& Jonathan B. Baker, Antitrust LaW in Perspective: Cases, Concepts and Problems in Competition Policy 358, 371-74 (2d ed. 2008).

40. 148 F.2d 416 (2d Cir. 1945).

41. Compare id., with E.I. du Pont de Nemours \& Co., 96 F.T.C. 653 (1980).

42. See Jonathan B. Baker, Predatory Pricing after Brooke Group: An Economic Perspective, 62 ANTITRUST L.J. 585 (1994) (describing Chicago school criticisms of predatory pricing theories); Edward A. Snyder \& Thomas E. Kauper, Misuse of the Antitrust Laws: The Competitor Plaintiff, 90 Mich. L. REV. 551 (1991) (contending that few lawsuits brought by rivals appeared meritorious).

43. The Chicago school's critics have conceded this point. See, e.g., LAWRENCE A. Sullivan \& Warren S. Grimes, The LaW of Antitrust: An Integrated Handbook $\S 1.3$, at 7 (2000) ("By the mid-1970s, a sense that some court decisions had suppressed conduct that was efficient and the contemporaneous growth in influence of the Chicago School of Economics began tempering enforcement policy.”); Robert Pitofsky, Does Antitrust Have a Future?, 76 GEO. L.J. 321, 323-25 (1987) (finding "much wrong with the overly aggressive antitrust enforcement policies of the 1960s" and commending the Supreme Court for moving "cautiously and thoughtfully in the direction of more lenient antitrust policies" since the mid-1970s through decisions that were "generally more solicitous toward claims of efficiency"); $c f$. Thomas E. Kauper, Influence of Conservative Economic Analysis on the Development of the Law of Antitrust, in How the CHICAGo SCHOOL Overshot THE Mark: The EFfect of Conservative Economic ANALYsis on U.S. ANTitrust 40, 42-44 (Robert Pitofsky ed., 2008) (while Chicago criticisms of the antitrust doctrines of the 1950s and 1960s were influential in bringing about change, those doctrines were often easy targets for ridicule and were also criticized by a number of influential non-Chicagoans, such as Phillip Areeda, Donald Turner, and Robert Pitofsky).

44. There is no reason to think that, as a group, these modifications to antitrust's rules simultaneously relaxed average deterrence but increased marginal deterrence, notwithstanding the theoretical possibility discussed supra note 15. 
mobilizing politically to replace an economic policy based on preferring competition with more direct regulation. ${ }^{45}$

After more than three decades during which antitrust rules were reworked to prevent them from chilling the pursuit of production efficiencies, the risk that the antitrust rules will permit large firms to exploit their market power to such a great extent that those rules will lose the support of the consumer coalition has increased. Today, this risk is substantially more serious than the opposite possibility, that the antitrust laws would be used to redistribute producer surplus to consumers and lead large firms to see no benefit from maintaining the bargain. For that reason, antitrust rules should now be implemented with reference to a qualified consumer welfare standard: antitrust institutions should adopt a consumer surplus standard in general, but allow firms to capture increased producer surplus if those gains are large and the lost consumer surplus is small. ${ }^{46}$ This is roughly how fixed cost savings from mergers are treated in the Horizontal Merger Guidelines. ${ }^{47}$ In practice, therefore, enforcers should target conduct that harms consumers, allowing efficiencies to trump consumer harm only in exceptional cases, and courts should similarly frame rules and decide cases to prevent consumer harm.

\section{THE END OF DEREGULATION}

To think about antitrust's possible futures, it is useful to broaden the lens and examine how economic regulatory policy has developed since the midtwentieth century within the informal political understanding I identified and to locate antitrust developments within this larger context. As competition policy is viewed within a wider frame of economic regulation, the political understanding must be described more broadly: as an informal mid-twentieth century social contract that combines social insurance with competition policy.

45. Progressive commentators writing today have expressed concern about the exercise of market power in large sectors of the economy. See, e.g., SusAn Crawford, CAPTIVE Audience: The Telecom Industry and Monopoly Power in the New Guilded Age (2013); BARry C. Lynn, CoRnered: The New Monopoly Capitalism AND the ECONOMics of Destruction (2010); cf. Margaret C. Levenstein, Antitrust and Business History, 85 S. CAL. L. REV. 451 (2012) (explaining that competition policy may unduly favor large firms). The contemporary progressive concern with social problems arising from increased inequality could also bring more political attention to the distributional consequences of antitrust rules. However, the most sustained and influential recent political mobilization has been conservative, from the Tea Party, not progressive.

46. Baker, supra note 1 , at 521-22. This standard would not be met if the efficiencies could practically be obtained in some other way that presents less harm to consumers. Although a qualified consumer welfare standard makes sense today, under different circumstances I might argue instead for more emphasis on producer surplus, as by shifting to an aggregate welfare standard.

47. Horizontal Merger Guidelines, supra note 13, § 10. 
I think of social insurance as related to competition policy politically. From this perspective, ${ }^{48}$ social insurance is a type of "side payment"-a way of sweetening the deal to induce political acceptance of a policy fostering competitive markets among consumers, farmers, workers, and their families. In general, consumers, farmers, and workers have difficulty insuring against the risks they have been asked to bear in a dynamic economy. These risks include unemployment and skill obsolescence. They also include the fraying of extended family networks that could otherwise help people spread income over their lifecycle, share in the costs of caring for retirees and children, and share healthcare costs. Competitive markets exacerbate these risks. Social insurance has historically been the most practical and cost-effective way to allocate such risks efficiently. ${ }^{49}$

Although I have described the political bargain as an arrangement reached by two diffuse interest groups, I interpret policy outcomes achieved within the political bargain as the product of an interest group competition mediated by ideology. ${ }^{50}$ I will therefore describe economic regulatory policy since the mid-twentieth century as arising from a political competition among centrists, noninterventionists on their right, and interventionists on their left. From this broader perspective, the centrist position endorses both parts of the informal mid-twentieth century understanding: competition policy for dealing with large firms and social insurance to provide a safety net. ${ }^{51}$ Conservative noninterventionists would prefer to rely more on self-regulation for the economy and more on private insurance to address risks, while progressive interventionists would prefer to rely more on direct regulation and the direct provision of social services like health care.

48. Social insurance also has other justifications, on grounds of efficiency (lowering the transaction costs of risk bearing) and equity. Social insurance may be implemented directly through government-run insurance programs or indirectly through tax policy.

49. But $c f$. Robert J. Shiller, The New Financial Order: RisK IN THE 21st Century (2003) (proposing financial instruments to lower the transaction costs of obtaining private insurance against various social risks); ROBERT J. SHILler, MACRO MARKETS: CREATING INSTITUTIONS FOR MANAGING SOCIETY’s LARGEST ECONOMIC RISKS (1993) (same).

50. Ideology helps solve an agency problem governing the relationship between interest group members (principals) and political leaders (agents). By committing to an ideological perspective, a political leader can signal to interest group members that when circumstances change or unanticipated issues arise after election, the leader will act consistent with the group's interests. In consequence, interest group members select leaders, at least, in part based on their ideological commitments. Doing so also facilitates monitoring of the leader's decisions by interest group members, as it may be easier to determine whether specific decisions by elected officials are consistent with an ideological perspective than to determine whether those decisions directly benefit the interest group's members.

51. When Governor Romney, the Republican candidate in the 2012 presidential election, expressed sympathy for government health insurance programs in his first debate with President Obama, commentators described his views as moving toward the center. See, e.g., Doyle McManus, Moderate Mitt? Don’t Count On It, L.A. Times, Oct. 7, 2012, at A28. 
The centrist approach to economic regulatory policy has been implemented since the New Deal, with a major change of emphasis along the way. For the first few decades, centrists partnered mainly with progressives on regulatory matters. For example, Medicare, a major safety net expansion, was enacted over the opposition of conservatives, who viewed it as inappropriate government intervention into the marketplace. ${ }^{52}$ During the Carter Administration, Senator Edward Kennedy and his committee counsel, future Justice Stephen Breyer, brought conservatives into the tent. The right found common ground with the center/left coalition in enacting airline deregulation. ${ }^{53}$ But the centrists later switched dancing partners when the left grew disenchanted with regulatory reform.

Since the Reagan Administration, accordingly, centrists have gotten their way on regulatory policy by collaborating with conservatives. Deregulation became a center/right program. ${ }^{54}$ It was wide-ranging across the transportation, communications, energy, and financial services sectors. ${ }^{55}$ The regulatory reforms were centrist rather than conservative because they preserved regulation where competition would be insufficient. For example, rate regulation remains for the transmission and retail distribution of electricity. ${ }^{56}$ Communications deregulation did not allow local phone companies to provide long distance service until the long distance market became competitive. ${ }^{57}$ Congress reversed cable deregulation in 1992 after eight years in which hoped-for competition did not appear, then refined its regulatory scheme four years later. ${ }^{58}$ Airline deregulation left safety

52. Jonathan Oberlander, The Politics of Medicare Reform, 60 WASH. \& LEE L. REV. 1095, 1099 (2003).

53. See Martha Derthick \& Paul J. Quirk, The Politics of Deregulation 122-23 (1985) (the political coalition favoring airline and trucking deregulation "covered most of the political spectrum," thereby demonstrating "the degree to which widely shared interests and values converged in support of reform”); Bradley Behrman, Civil Aeronautics Board, in THE Politics of Regulation 75, 120 (James Q. Wilson ed., 1980) (airline deregulation legislation passed Congress almost unanimously).

54. See Monica Prasad, The Politics of Free Markets: The Rise of Neoliberal Economic Policies in Britain, France, Germany, \& the United States 62-82 (2006) (deregulation was viewed as proconsumer (liberal) during the early 1970s, in the national interest during the mid-1980s, and probusiness (conservative) in the late 1970s).

55. See generally Clifford Winston, Economic Deregulation: Days of Reckoning for Microeconomists, 31 J. ECON. LITERATURE 1263 (1993).

56. See Staff Report, FTC, Competition and Consumer Protection Perspectives ON ELECTRIC POWER REgUlatory REFORM (2000), available at http://www.ftc.gov/ be/v000009.shtm. Similarly, rail deregulation did not eliminate the power to regulate shipping rates of dominant rail carriers. See James Calderwood, Legal Briefs: Should Rail Rates Be Regulated Again?, MH\&L NEws (Apr. 4, 2006), http://mhlnews.com/ transportation-amp-distribution/legal-briefs-should-rail-rates-be-regulated-again.

57. Jonathan E. Neuchterlein \& Philip J. Weiser, Digital Crossroads: American Telecommunications Policy in the Internet Age 88 (2005).

58. Stuart Minor Benjamin et al., Telecommunications LaW and Policy 456-57 (3d ed. 2012). 
regulation in the hands of the Federal Aviation Administration (FAA), not relying solely on marketplace incentives to keep planes from falling out of the sky. ${ }^{5}$

Deregulation has, on the whole, been a success, particularly for consumers. ${ }^{60}$ Financial deregulation was a partial exception, as is evident from the costly problems with savings and loans during the $1980 \mathrm{~s}^{61}$ and with nonbank financial institutions and markets more recently. ${ }^{62}$ These problems arose in part because centrists misjudged the need for residual government supervision. In consequence, financial regulators were not led to approach their task the way the FAA supervises airline safety.

I understand the shift in the coalition that controlled economic regulatory policy-moving from center/left to center/right—as the product of two main factors. In part, it was a reaction to a difficult economic environment. The decade of economic stagnation that began during the 1970s included two oil shocks, inflation, three recessions, a productivity slowdown, sluggish income growth for workers, and increased foreign competition for domestic industries. ${ }^{63}$ The shifting coalition was also a reaction to the increased federal role in economic life, which resulted particularly from legislation protecting civil rights, the environment, and worker safety. ${ }^{64}$ These factors combined to favor a regulatory reform agenda aimed at increasing productivity by attacking excessive regulation, including both deregulation and reforms of the antitrust laws. That agenda was implemented within the political bargain, not by rejecting it.

59. See generally Transp. Research BD., NAT'L Research Council, Winds of Change: Domestic Air Transport Since Deregulation 169-98 (1991).

60. See generally MAS-COLELL, supra note 5.

61. See generally Lawrence J. White, The S\&L Debacle: Public Policy Lessons FOR BANK AND THRIFT REGULATION (1991).

62. Gary Gorton \& Andrew Metrick, Getting Up to Speed on the Financial Crisis: A One-Weekend-Reader's Guide, 50 J. ECON. LITERATURE 128, 132 (2012) (at the time of the 2008 financial crisis, the "main vulnerability" of the "shadow banking system" to the equivalent of a bank run was in financial markets for short term debt, mostly repurchase agreements and commercial paper, which were both large and unregulated); Andrew W. Lo, Reading About the Financial Crisis: A Twenty-One Book Review, 50 J. ECON. LiterAture 151, 157-58 (2012) (recounting the view that a lack of transparency in markets for securitized debt led to a collapse in trading in structured investment vehicles and a stall in the markets for repurchase agreements); id. at 161 (recounting the view that after financial industry regulation was dismantled, "too big to fail" financial institutions took excessive risks); id. at 162-63 (recounting the view that financial deregulation and regulatory capture permitted industry concentration and facilitated financial innovation, making the financial system prone to recurrent crises).

63. See Laura Kalman, Right Star Rising: A New Politics, 1974-1980, at 38-63 (2010); Alan S. Blinder \& Jeremy B. Rudd, The Supply-Shock Explanation of the Great Stagflation Revisited, in The Great Inflation: The Rebirth of Modern Central BANKING (Michael D. Bordo \& Athanasios Orphanidees eds., 2013).

64. See Kim Phillips-Fein, Invisible Hands: The MaKing of the Conservative Movement FROM the New DEAL to REAGAN 185-225 (2009). 
Although the centrist approach to economic regulation has been accepted for decades, it is now under pressure. Today, remarkably, we see a simultaneous discontent with the centrist approach from both sides, the right as well as the left. On the right, conservative senators held up confirmation of the Director of the Consumer Financial Protection Bureau in a bid to water down the agency's powers and independence, forcing the White House to make a recess appointment. ${ }^{65}$ The House of Representatives, under the sway of conservatives, sought to overrule the Federal Communications Commission's open internet rules on net neutrality, although they were thwarted by the Senate. ${ }^{66}$ In 2003, during the Bush Administration, competition-oriented centrists worked with compassionate conservatives to add a prescription drug benefit to Medicare. ${ }^{67}$ But when the Affordable Care Act (Obamacare) was enacted in 2010, conservatives walked away from market-based reforms that their camp had previously endorsed, 68 and during 2012, the entire Republican presidential field called for the Act's repeal. ${ }^{69}$ On the left, the Occupy Wall Street movement criticized the Dodd-Frank financial reforms as too little, too late. ${ }^{70}$ Progressives did not embrace the 2003 prescription drug benefit, on the grounds that it was an expensive handout to pharmaceutical manufacturers and that its reliance on insurance companies was the first step toward privatizing Medicare. ${ }^{71}$ Progressive support for the 2010 health care law was muted, just sufficient for congressional enactment, because progressives preferred a government-run system like Medicare to the Affordable Care Act's competition-based approach. ${ }^{72}$

65. Helene Cooper \& Jennifer Steinhauer, Bucking Senate, Obama Appoints Consumer Chief, N.Y. Times, Jan. 4, 2012, at A1.

66. Peter Voskamp, GOP Attempt To Overturn FCC's Net Neutrality Rules Fails in Senate, REUTERS (Nov. 10, 2011), http://www.reuters.com/article/2011/11/10/idUS211 494328220111110.

67. See Oberlander, supra note 52, at 1133-36; Christine Hauser, President Signs Medicare Bill Adding Prescription Drug Benefit, N.Y. Times (Dec. 8, 2003), http://www.nytimes.com/2003/12/08/politics/08CND-BUSH.html.

68. Ezra Klein, Unpopular Mandate, NEw YoRKeR (June 25, 2012), http://www. newyorker.com/reporting/2012/06/25/120625fa_fact_klein.

69. Nellie Bristol, Republican Presidential Candidates United on Healthcare, 379 LANCET 107 (2012).

70. Matt Stoller, The False Dodd-Frank Narrative: Occupy Wall Street Attacks Huge Hot Money Loophole in the Law, NAKed CAPITALISM (Nov. 6, 2012, 1:43 PM), http://www.nakedcapitalism.com/2012/11/the-false-dodd-frank-narrative-occupy-wall-streetattacks-huge-hot-money-loophole-in-the-law.html.

71. See Reihan Salam, Brief Note on Paul Ryan and the Medicare Prescription Drug Benefit, NAT'L REV. ONLINE (Aug. 12, 2012), http://www.nationalreview.com/ agenda/313766/brief-note-paul-ryan-and-medicare-prescription-drug-benefit-reihan-salam\#.

72. See Theda Skocpol, Naming the Problem: What It Will Take To Counter Extremism and Engage Americans in the Fight Against Global Warning, Scholars STRATEgy NETWORK, 39-44 (Jan. 2013), http://www.scholarsstrategynetwork.org/sites/default/files/ skocpol_captrade_report_january_2013_0.pdf; David M. Herszenhorn \& Robert Pear, Final 
Every regulation has its critics, but the current turmoil is surprising because the Obama Administration has followed the same centrist playbook for economic regulation that has succeeded since the Reagan Administration. The standard playbook is failing because the center/right coalition has broken down. Conservative opponents of "big government" no longer seem willing to compromise with centrists. Moreover, the center/right coalition may have run its natural course, as its core program has largely become obsolete. After decades of regulatory reform, additional deregulation now risks removing regulatory supervision in industries where doing so would allow the exercise of market power, create other market failures, or undermine the safety net. More deregulation now would tend to advance a noninterventionist agenda while impeding centrist goals, not by enhancing competition and social insurance. ${ }^{73}$

Antitrust policy illustrates the current tensions in the center/right coalition. During the 1980s, even Robert Pitofsky, a leading liberal antitrust voice, accepted the need for reform. ${ }^{74}$ But today the Chicago school's program, like deregulation generally, is largely complete. A few years ago, Judge Douglas Ginsburg described the rule against tying as the "last man standing," 75 indicating how far the Chicago-oriented reformation of antitrust rules has come.

In recent years, antitrust conservatives have been advancing a noninterventionist program that does not appear to seek compromise with centrists. I have in mind the section 2 report from the Justice Department during the George W. Bush Administration, ${ }^{76}$ which the Federal Trade Commission pointedly refused to join and the Obama Administration withdrew. ${ }^{77}$ I am also thinking of Justice Scalia's defense of monopoly as an important element of the free enterprise system in Verizon

Votes in Congress Cap Battle on Health Bill, N.Y. Times (Mar. 25, 2010), http://www.nytimes.com/2010/03/26/health/policy/26health.html; Jeff Zeleny \& Robert Pear, Kucinich Switches Vote on Health Care, N.Y. Times (Mar. 17, 2010), http://prescriptions.blogs.nytimes.com/2010/03/17/kucinich-switches-vote-on-health-care/.

73. Cf. Mark Tushnet, The New Constitutional Order 32 (2003) (noting that the modern constitutional order that has supplanted the New Deal-Great Society order preserves baseline protections for some quality-of-life programs and the social safety net but cannot use the government to solve any new problems).

74. See Pitofsky, supra note 43, at 323-25.

75. The author heard Judge Ginsburg make this comment during his remarks at the Luncheon Roundtable Discussion with Federal Courts of Appeals Judges at the ABA Section of Antitrust Law Spring Meeting on Mar. 25, 2009.

76. U.S. Dep't of Justice, Competition and Monopoly: Single-Firm Conduct UNDER SECTION 2 OF THE SHERMAN ACT 12-13 (2008), available at http://www.justice.gov/ atr/public/reports/236681.pdf.

77. Press Release, U.S. Dep’t of Justice, Justice Department Withdraws Report on Antitrust Monopoly Law (May 11, 2009), available at http://www.usdoj.gov/atr/ public/press_releases/2009/245710.htm. 
Communications Inc., v. Trinko. ${ }^{78}$ Justice Scalia went out of his way to make that argument: in the context of the decision, the discussion was dicta, ${ }^{79}$ and he could have made his economic point by talking about appropriability as a spur to innovation without seeming to welcome monopolies. In addition, recent Supreme Court decisions seem to evidence an interest in chipping away at private antitrust enforcement; ${ }^{80}$ this is a possible theme connecting Trinko, ${ }^{81}$ Credit Suisse Securities (USA) LLC v. Billing, ${ }^{82}$ Bell Atlantic Corp v. Twombly, ${ }^{83}$ and the Court's acceptance of certiorari in Behrend v. Comcast Inc. ${ }^{84}$

\section{ANTITRUST FUTURES}

This perspective on the evolution of regulatory policy provides a window into possible futures for antitrust. These speculations are just that: sketches of ways that competition policy in the United States might evolve based on the framework set forth above, relying more on conjecture than evidence.

One possibility is that the center/right coalition will fall apart, leading to regulatory gridlock. ${ }^{85}$ If so, antitrust enforcement policy and judicial rules might not change substantially, but the political jockeying to control the framework governing economic regulatory policy could turn competition matters that previously would have been treated as routine law enforcement

78. 540 U.S. 398 (2004) (holding that a nonantitrust statutory scheme providing for extensive regulation aimed at promoting competition in telephony displaced private enforcement under the Sherman Act).

79. The Court held that an antitrust claim could not proceed in a setting in which a separate statutory scheme provided for extensive regulation aimed at promoting competition.

80. Daniel A. Crane, The Institutional Structure of Antitrust Enforcement 6263 (2011).

81. See Trinko, 540 U.S. at 414 ("Judicial oversight under the Sherman Act would . . lead to a new layer of interminable litigation .....”) (holding that the plaintiff customer class failed to state a claim under the Sherman Act).

82. 551 U.S. 264, 281-82 (2007) (highlighting the risk of inconsistent outcomes and "antitrust mistakes" if private antitrust plaintiffs bring lawsuits "in dozens of different courts with different nonexpert judges and different nonexpert juries”). Wariness about private antitrust enforcement also helps explain why a conservative Supreme Court would prefer regulation to antitrust in Trinko and Credit Suisse.

83. 550 U.S. 544 (2007) (holding that allegations must be plausible, not merely possible, to survive a motion to dismiss for failure to state a claim).

84. 655 F.3d 182 (3d Cir. 2011), cert. granted, 133 S. Ct. 24 (Jun. 25, 2012) (No. 11864) (considering standards for certifying a plaintiff class on the facts of an antitrust case).

85. Cf. Jack M. Balkin, What It Will Take for Barack Obama To Become the Next FDR, AtLANTIC (Nov. 1, 2012, 8:01 AM), http://www.theatlantic.com/politics/archive/ 2012/11/what-it-will-take-for-barack-obama-to-become-the-next-fdr/264195/ (describing Obama as a "preemptive" President, swimming against a conservative tide). The "median voter theorem" suggests that centrist views will tend to control in political institutions that operate by majority rule, MaXwell L. STEARns \& TodD J. Zywicki, Public Choice CONCEPTS AND APPLICATIONS IN LAW 97 (2009). But that model does not account for the role of ideologically-cohesive voting groups, or illustrate the possibility that bargaining among those groups would break down, leading to gridlock. 
matters into subjects for political conflict. ${ }^{86}$ This already happens to a limited extent: members of Congress occasionally take sides on highprofile government antitrust investigations, and the firms involved occasionally seek to mobilize political support. ${ }^{87}$ With regulatory gridlock, political interest in enforcement decisions and judicial outcomes could become less exceptional.

Some room would remain for antitrust enforcement priorities to shift without political change, through enforcement agency case selection. Suppose, for example, that recession, unemployment, and fiscal issues become less of a preoccupation for economic policy, as might happen with greater progress toward economic recovery and a resolution of the political debate over the federal budget, taxes, and the future solvency of entitlement programs. Under such circumstances, concerns about long term economic growth may increase in salience, increasing the focus of competition enforcement on promoting innovation and growth notwithstanding a growing difficulty with formulating consistent regulatory policy generally. ${ }^{88}$

Another possibility involves a decisive political realignment that would place one of the three ideological groups-conservatives, centrists, or progressives - in control of all three branches of government for a sustained period. Then that group would be able to set regulatory policy on its own, without the need to form a coalition with any other group. The policy specifics would depend on which group takes charge of economic regulatory policy. A realignment that favors either conservatives or progressives would mark an end to the political bargain, ${ }^{89}$ while realignment in favor of centrists would likely reaffirm the existing political

86. For similar reasons, it would become increasingly difficult to build a political consensus in support of many agency rules implementing statutory mandates in the broader realm of economic regulation, from the environment to the internet, and any rules that are implemented may face routine court challenges and increasingly searching judicial review regardless of their content.

87. See, e.g., Brent Kendall et al., Behind Google's Antitrust Escape, WALL ST. J., Jan. 5, 2013, at B3; Kim Hart \& Anna Palmer, AT\&T's T-Mobile Merger Lobbying Campaign Falls Short, POLITICO (Sept. 1, 2011, 9:19 AM), http://www.politico.com/news/stories/ 0911/62472.html.

88. On the connection between competition policy and economic growth, see Jonathan B. Baker, Beyond Schumpeter vs. Arrow: How Antitrust Fosters Innovation, 74 ANTITRUST L.J. 575, 579 (2007); Baker, supra note 17 (section III.B) (highlighting the particular threat anticompetitive exclusion poses to economic growth); Carl Shapiro, Competition and Innovation: Did Arrow Hit the Bull's Eye?, in The RATE AND DiRection OF Inventive ACTiVity Revisited 361 (Josh Lerner \& Scott Stern eds., 2012).

89. See generally Baker, supra note 1 , at 483 . The losing side would likely mobilize politically to overturn its electoral defeat. As a result, regulatory and antitrust policies may become politicized and unstable for decades, much as the nation experienced during the early twentieth century, leading to the loss of the efficiency gains that flowed from adopting a competition policy as the primary economic regulatory approach. 
understanding. ${ }^{90}$ It is hard to say more about the consequences of a political realignment for antitrust or regulatory policy without speculating about the nature of the circumstances that precipitate thoroughgoing political change. ${ }^{91}$

Putting aside the possibility of realignment, two other future outcomes could arise within the existing political framework if the centrists can find allies. One possibility is that the conservatives and the centrists may restore their alliance. If they do, they would need a new affirmative agenda, as deregulation has likely run its course. Conservative concerns that regulation and regulatory uncertainty discourage investment and growth may offer a theme that would allow a restored center/right alliance to protect what it has achieved in three decades of deregulation, but this theme would be unlikely to lead to substantial changes in antitrust and regulatory policy. Such an outcome would appear different from regulatory gridlock mainly in that competition policy issues would be less politicized in public debate.

The final future possibility is that the center and left would find common ground, as they previously did in the middle of the twentieth century. One plausible theme for such a coalition would be a concern with the power of large firms in concentrated markets-combining a concern with economic power, which may be the more important issue for centrists, and a concern with political power, which may be more important for the left. ${ }^{92}$ This theme could tie episodic political debates over the power of large banks, oil companies, and health insurers to the consequences of corporate political influence, in order to frame a broader political conversation. A center/left coalition would maintain the political bargain. Antitrust policy most likely would remain focused on economic goals but with the rules reformed to lessen the threat that firms would exercise market power. Rules governing exclusionary conduct, and related procedural rules governing private

90. Specific regulatory and antitrust policies might drift away from the noninterventionist pole in the current U.S. debate, though, as those policies would no longer be shaped in part by conservatives.

91. For example, a sustained period of slow economic growth could lead an interest group to conclude that its share of the efficiency gains from acceding to the political bargain in favor of competition policy would no longer exceed the gains the group could obtain by mobilizing politically to capture government institutions and subvert the political bargain by altering regulatory policy to redistribute in its favor.

92. See, e.g., LAWRENCE Lessig, Republic, LOST: How MONEy CORRUPTS CONGRESSAND A PLAN To STOP IT (2011). Similarly, some conservative commentators, particularly those writing in the public choice tradition, are concerned about the dangers of "crony capitalism.” See, e.g., Luigi Zingales, A Capitalism for the PeOPle: ReCAPturing the LOST GENIUS OF AMERICAN Prosperity (2012). For Zingales, "the most powerful argument in favor of antitrust law" is that it "reduces the political power of firms." Id. at 38. 
litigation, might change the most, as the norms governing exclusion are likely the most contested today. ${ }^{93}$

Although an opportunistic center/left coalition enacted health care reform and adopted new financial legislation during President Obama's first term, it is hard to imagine a more consistent center/left alliance gaining control of economic regulatory policy so long as conservatives dominate the House of Representatives and the Supreme Court. ${ }^{94}$ For that reason, a successful center/left coalition may be predicated on an electoral shift, ${ }^{95}$ albeit one short of a broad political realignment, and the replacement of a conservative Justice by a more liberal one.

Politics, like life itself, has a way of bringing surprises. Competition law and economic regulatory policy may not develop along any of the lines sketched above. Still, this exercise suggests that regulatory policyantitrust included-is unlikely to change substantially unless and until outside events or demographic shifts lead to significant political change.

\section{ECONOMICS AND POLITICS IN ANTITRUST: A CONCLUDING COMMENT}

The modifications to antitrust rules during the 1980s followed, to a substantial extent, the recommendations of Judges Bork and Posner, who were heavily influenced by Chicago school economics. ${ }^{96}$ More recent antitrust enforcement and policy initiatives have incorporated later developments in economics. ${ }^{97}$ Here I have in mind, for example, the acceptance of unilateral effects analysis in merger review; ${ }^{98}$ the gametheoretic elaboration of the Stiglerian deterrence model of coordination and its application to the problems of inferring agreement from circumstantial evidence $^{99}$ and evaluating coordinated effects of mergers; ${ }^{100}$ the application

93. See generally Baker, supra note 88. Outside of the antitrust world, a center/left regulatory policy might also reduce the scope of intellectual property rights.

94. See, e.g., Polarization Is Real (and Aysmmetric), Voteview (May 16, 2012), http://voteview.com/blog/?p=494 (analyzing congressional polarization).

95. Cf. Balkin, supra note 85 ("[I]t will probably take a third Democratic presidency to finally end the age of Reagan.”).

96. See generally Bork, supra note 4; Richard A. Posner, AnTitrust Law (1st ed. 1976).

97. I provided a prospective sketch of some of these ideas in Jonathan B. Baker, Recent Developments in Economics That Challenge Chicago School Views, 58 ANTITRUST L.J. 645 (1989). When the notes to the next sentences cite my survey articles, the point is to avoid extensive literature reviews in the margin, not to downplay the contributions of others.

98. Horizontal Merger Guidelines, supra note 13, § 6. See generally Jonathan B. Baker, Why Did the Antitrust Agencies Embrace Unilateral Effects?, 12 GEO. MAson L. REV. 31 (2003).

99. See generally Jonathan B. Baker, Two Sherman Act Section 1 Dilemmas: Parallel Pricing, the Oligopoly Problem, and Contemporary Economic Theory, 38 ANTITRUST BulL. 143 (1993); Louis Kaplow, An Economic Approach to Price Fixing, 77 AnTITRUst L.J. 343 (2011).

100. See, for example, the increased focus on the role of mavericks in merger analysis. See Horizontal MerGer Guidelines, supra note 13, § 2.1.5; see also Jonathan B. Baker, 
of the "raising rivals' costs" framework and the recent economic literature on foreclosure to evaluating exclusionary conduct; ${ }^{101}$ the application of modern economic learning on "two-sided" platforms in markets with network effects to evaluating firm conduct; ${ }^{102}$ and the increased application of econometrics ${ }^{103}$ and merger simulation ${ }^{104}$ in antitrust enforcement and litigation.

As this sketch of developments suggests, economics plays an overwhelming role in shaping antitrust thinking and analysis today. For that reason, it is not surprising that some commentators describe modern antitrust as largely a technocratic activity based on economic analysis. 105 Yet, as indicated above, it is impossible to view the evolution of antitrust without seeing politics as well as economics. My vision of antitrust's goals and future recognizes the political context of antitrust while simultaneously embracing the central role of economics in the field. So long as competition policy remains the product of a political understanding aimed at capturing economic efficiencies, as it should, economic analysis will remain the essence of antitrust policy, enforcement, and litigation.

Mavericks, Mergers, and Exclusion: Proving Coordinated Competitive Effects Under the Antitrust Laws, 77 N.Y.U. L. REV. 135 (2002). Coordination that takes the form of parallel accommodating conduct accounts for types of oligopoly behavior going beyond the Stiglerian deterrence model. See HorizonTAL MERgER Guidelines, supra note 13, § 7.

101. Baker, supra note 88; Thomas G. Krattenmaker \& Steven C. Salop, Anticompetitive Exclusion: Raising Rivals’ Costs To Achieve Power over Price, 96 YALE L.J. 209 (1986).

102. David S. Evans \& Richard Schmalensee, The Industrial Organization of Markets with Two-Sided Platforms, 3 COMPETITION POL'y INT'L 151 (2007); Janusz A. Ordover, Comments on Evans \& Schmalensee's "The Industrial Organization of Markets with TwoSided Platforms,” 3 COMPETITION POL'y INT'L 181 (2007).

103. Jonathan B. Baker \& Daniel L. Rubinfeld, Empirical Methods in Antitrust Litigation: Review and Critique, 1 AM. L. \& ECON. REV. 386 (1999).

104. Jonathan B. Baker, Merger Simulation in an Administrative Context, 77 ANTITRUST L.J. 451 (2011); Gregory J. Werden \& Luke M. Froeb, Unilateral Competitive Effects of Horizontal Mergers, in HANDBOOK OF AnTITRust ECONOMics 43 (Paolo Buccirossi ed., 2008).

105. Daniel A. Crane, Technocracy and Antitrust, 86 TeXAs L. Rev. 1159 (2008); cf. William E. Kovacic, The Modern Evolution of U.S. Competition Policy Enforcement Norms, 71 AntitRust L.J. 377, 378-81 (2003) (questioning a narrative that depicts antitrust enforcement as prone to pendulum swings). 